\title{
PENGARUH KEBERADAAN LAYANAN FILIAL KPPN POSO DI MOROWALI BAGI SATUAN KERJA WILAYAH KABUPATEN MOROWALI DAN MOROWALI UTARA
}

Faisal Amin

KPPN Poso

Alamat Korespondensi: faisal.amin@kemenkeu.go.id

\section{INFORMASI ARTIKEL}

Diterima Pertama

31 Juli 2017

Dinyatakan Diterima

30 Juli 2018

KATA KUNCI:

National Budget, Goverment Expenditures, Fund Disbursement

KLASIFIKASI JEL:

H50,031,038

\begin{abstract}
This research analyzed the influence the existence of KPPN Poso's filial service in Morowali. This analyzes is done by compare service volume output Surat Perintah Pencairan Dana (SP2D) issued and consultation customer service officer by KPPN Poso before and after KPPN Poso's filial service in Morowali was created. This research uses time series from October 2015 to September 2016 (before KPPN Poso's filial service in Morowali created) and October 2016 to September 2017 (after KPPN Poso's filial service in Morowali created), both of them have same time series which is 1 year. The results indicated that the existence of KPPN Poso's filial service in Morowali making the work units in Morowali and North Morowali become easier to get services from KPPN Poso.
\end{abstract}

\section{ABSTRAK}

Penelitian ini menganalisis pengaruh keberadaan layanan filial KPPN Poso di Morowali. Analisis ini dilakukan dengan membandingkan volume output layanan berupa Surat Perintah Pencairan Dana (SP2D) yang diterbitkan dan layanan konsultasi customer service officer KPPN Poso sebelum serta sesudah layanan filial KPPN Poso di Morowali dibentuk. Penelitian ini menggunakan time series dari bulan Oktober 2015 sampai September 2016 (sebelum layanan filial KPPN Poso di Morowali dibentuk) dan bulan Oktober 2016 sampai September 2017 (sesudah layanan filial KPPN Poso di Morowali dibentuk), yang keduanya berjangka waktu sama yaitu 1 tahun. Hasil yang didapatkan menunjukkan bahwa keberadaan layanan filial KPPN Poso di Morowali memudahkan satuan kerja wilayah Kabupaten Morowali dan Morowali Utara untuk mendapatkan layanan dari KPPN Poso. 


\section{PENDAHULUAN}

\subsection{Latar Belakang}

Pemerintah berkewajiban melayani setiap warga negara untuk memenuhi hak dan kebutuhannya dalam hal yang bersifat pelayanan publik. Hal tersebut telah diatur dalam Undangundang Nomor 25 Tahun 2009 tentang Pelayanan Publik. Pemerintah dalam hal ini Kementerian Keuangan berkewajiban melayani setiap warga negara yang berhubungan dengan keuangan negara mulai dari penerimaan perpajakan, penerimaan hasil cukai, hingga pengeluaran negara. Dalam menatausahakan seluruh pengeluaran negara, Kementerian Keuangan menyerahkan tugas kepada Eselon 1 nya yaitu Direktorat Jenderal Perbendaharaan (DJPb).

Kantor Pelayanan Perbendaharaan Negara (KPPN) adalah instansi vertikal yang dimiliki oleh $\mathrm{DJPb}$ yang tersebar di berbagai kota/kabupaten seluruh Indonesia. KPPN mempunyai tugas melaksanakan kewenangan perbendaharaan dan Bendahara Umum Negara (BUN), penyaluran pembiayaan atas beban negara, serta penatausahaan penerimaan dan pengeluaran anggaran melalui dan dari kas negara berdasarkan peraturan perundang-undangan. Mitra kerja dari KPPN salah satunya adalah seluruh satuan kerja (satker) yang berada di wilayah pembayaran KPPN serta kegiatan operasionalnya biayai oleh APBN. Diharapkan dengan adanya KPPN di seluruh Indonesia dapat mempermudah satker dalam mencairkan dananya sehingga kegiatan operasional satuan kerja dapat berjalan dengan baik.

Meskipun keberadaan KPPN telah tersebar di seluruh wilayah Indonesia, namun masih terdapat beberapa satker yang mengalami kesulitan untuk datang ke KPPN. Hal ini dikarenakan kondisi geografis Indonesia yang terdiri dari pulau-pulau kecil, jarak antar daerah satu dengan yang lain sangat jauh, serta sarana infrastruktur, berupa jalan dan jembatan yang masih belum memadai. Kondisi tersebut sering dijumpai di Indonesia, terutama di luar Pulau Jawa. Berdasarkan hal tersebut, DJPb membuat suatu layanan untuk menyikapi permasalahan tersebut dengan membentuk layanan Filial KPPN dan Mobile KPPN.

Layanan Filial KPPN atau KPPN Filial adalah layanan front office KPPN yang ditempatkan di daerah yang jauh atau sulit ditempuh, dalam rangka mendekatkan pelayanan kepada satker, dan dilaksanakan oleh pegawai yang berasal dari KPPN Induk. Sedangkan, Layanan Mobile KPPN atau KPPN Mobile adalah layanan front office KPPN yang ditempatkan di mobil layanan dalam rangka meningkatkan dan mendekatkan pelayanan kepada satker. Melalui layanan Filial KPPN dan Mobile KPPN, diharapkan dapat memudahkan satkeruntuk melakukan penarikan dana di KPPN.

KPPN Poso memilki wilayah kerja antara lain, Kabupaten Poso, Kabupaten Tojo Una-Una, Kabupaten Morowali, dan Kabupaten Morowali Utara. KPPN Poso merupakan salah satu KPPN yang memberikan layanan Filial KPPN kepada satker lingkup kerjanya. Layanan Filial KPPN Poso berada di Bungku Kabupaten Morowali yang berjarak kurang lebih $250 \mathrm{~km}$ dari Kabupaten Poso. Layanan Filial KPPN Poso melayani satuan kerja lingkup Kabupaten Morowali dan Kabupaten Morowali Utara. Layanan Filial KPPN Poso mulai beroperasi bulan Oktober 2016 hingga saat ini. Dengan adanya Layanan Filial KPPN Poso, diharapkan terjadi peningkatan layanan yang diberikan kepada satuan kerja.

Berdasarkan latar belakang tersebut, penulis melakukan penelitian terhadap efektivitas layanan filial KPPN Poso di Morowali yang diberikan oleh KPPN Poso. Ruang lingkup penelitian ini adalah analisis efektivitas layanan filial KPPN Poso, dengan melihat pengaruh keberadaan layanan filial KPPN Poso di Morowali, melalui volume output layanan yang diberikan KPPN Poso sebelum serta sesudah layanan filial KPPN Poso di Morowali dibentuk.

\subsection{Ruang Lingkup}

Penulis membatasi ruang lingkup penelitian ini, dengan memfokuskan penelitian pada efektivitas layanan filial KPPN Poso di Morowali, melalui volume tagihan yang masuk di layanan filial KPPN Poso. Selain itu, penulis membatasi indikator efektivitas layanan filial KPPN Poso di Morowali, hanya dari tagihan yang masuk, tidak dari layanan rekonsiliasi, konfirmasi penerimaan, dan layanan konsultasi customer service officer.

\subsection{Masalah Penelitian}

Masalah dalam penelitian ini adalah apakah keberadaan layanan filial KPPN Poso di Morowali sudah cukup efektif bagi satuan kerja wilayah Kabupaten Morowali dan Morowali Utara.

\subsection{Tujuan Penelitian}

Penelitian ini bertujuan untuk mengetahui efektivitas dari keberadaan layanan filial KPPN Poso di Morowali bagi satuan kerja wilayah Kabupaten Morowali dan Morowali Utara.

\subsection{Manfaat Penelitian}

Penulis mengharapkan penelitian ini dapat bermanfaat bagi pemerintah, khususnya Direktorat Jenderal Perbendaharaan, Kementerian Keuangan, sebagai bahan informasi untuk pembukaan layanan filial KPPN selanjutnya. Selain itu, penulis 
juga mengharapkan penelitian ini dapat menjadi bahan referensi pada studi bidang keuangan atau perbendaharaan.

\section{KERANGKA TEORI}

\subsection{KPPN Poso}

KPPN Poso merupakan salah satu instansi vertikal dibawah naungan Direktorat Jenderal Perbendaharaan, Kementerian Keuangan. Sebelum reorganisasi Kementerian Keuangan, KPPN Poso bernama, Kantor Perbendaharaan dan Kas Negara (KPKN) Poso. KPPN Poso berada dan bertanggung jawab langsung kepada Kantor Wilayah DJPb Provinsi Sulawesi Tengah, sesuai dengan Keputusan Menteri Keuangan RI No. 214/KMK.1/2005 tanggal 02 Mei 2005.

KPPN Poso berdiri pada tahun 1973 dengan nama Kantor Bendaharawan Negara (KBN) Poso, yang kemudian pada tahun 1981 dibagi menjadi dua kantor yaitu Kantor Perbendaharaan Negara (KPN) dan Kantor Kas Negara (KKN). Pada masa itu KPN bertugas memeriksa tagihan yang dibebankan kepada negara dan menerbitkan Surat Perintah Membayar (SPM), dan KKN bertugas sebagai bendaharawan umum atas dasar SPM yang diterbitkan oleh KPN Poso, membayar secara tunai kepada yang berhak. Pada masa itu, semua penerimaan dan pengeluaran negara diterima dan dibayar secara tunai kepada KKN. Pada tahun 1990 KPN dan KKN Poso ini digabung menjadi satu dengan nama KPKN. Sejak penggabungan dua kantor ini, KPKN membuka rekening pada bankbank BUMN dan bank-bank swasta sebagai Bank Operasional dan Bank Persepsi, dan tidak lagi membayar dan menerima secara tunai semua pengeluaran dan penerimaan Negara. Pada masa itu, fungsi Kantor Perbendaharaan dilaksanakan oleh seksi Perbendaharaan sedangkan fungsi KKN dilaksanakan oleh seksi bendaharawan umum.

Sesuai dengan KMK No.303/KMK.01/2004 tanggal 23 Juni 2004 tentang Organisasi dan Tata Kerja Kantor Wilayah Direktorat Jenderal Perbendaharaan, dan Kantor Pelayanan Perbendaharaan Negara, KPKN berganti nama menjadi Kantor Pelayanan Perbendaharaan Negara (KPPN). Sehingga berganti pula nama KPKN Poso menjadi KPPN Poso. Pergantian ini tidak hanya menyangkut nama organisasi saja, namun juga susunan organisasi serta tugas dan fungsinya turut berubah. Kemudian pada tahun 2012, KPPN Poso menjadi KPPN Percontohan. Pada tahun 2015, KPPN Poso memiliki 4 kabupaten wilayah kerja, antara lain, Kabupaten Poso, Kabupaten Tojo UnaUna, Kabupaten Morowali, dan Kabupaten Morowali Utara. Kabupaten Morowali menjadi wilayah yang terjauh dari KPPN Poso sekitar kurang lebih 250 km dari Kabupaten Poso.

\subsection{Layanan Filial KPPN Poso}

Kondisi geografis Indonesia yang luas, dan juga memiliki ribuan pulau, menyebabkan ada beberapa lokasi yang sulit dijangkau. Belum lagi perjalanan yang harus ditempuh dengan waktu yang lama untuk mencapai daerah tertentu. Hal itu dirasakan oleh beberapa satker yang harus menempuh perjalanan ratusan kilometer, hanya untuk datang ke KPPN terdekat. Faktor perjalanan jauh juga menghambat satker untuk menikmati layanan yang diberikan oleh KPPN. Dalam rangka memudahkan para satker, untuk mendapatkan layanan dari KPPN, maka DJPb membentuk layanan filial.

Layanan filial KPPN mempunyai tugas melaksanakan kegiatan front office KPPN di wilayah kerja yang telah ditetapkan. Layanan filial KPPN menyelenggarakan fungsi penerimaan SPM, serta pengujiannya, konfirmasi setoran penerimaan, rekonsiliasi laporan keuangan, dan layanan konsultasi customer service officer. Layanan filial KPPN dibentuk dengan mempertimbangkan beberapa kriteria, yaitu letak serta kondisi geografis wilayah kerja, kondisi sarana prasarana transportasi yang tersedia, jumlah satuan kerja yang dilayani, volume SPM, dan ketersediaan jaringan komunikasi. Apabila kriteria tersebut terdapat pada wilayah kerja KPPN, maka KPPN dapat mengusulkan untuk didirikan layanan filial KPPN. Pembentukan layanan filial KPPN diatur tersendiri, melalui Peraturan Dirjen Perbendaharaan PER-7/PB/2012.

Pembentukan layanan filial KPPN Poso di Morowali, diawali dari keinginan para peserta seminar evaluasi realisasi penyerapan anggaran satker KPPN Poso pada tanggal 8 Oktober 2015 di Morowali, yang merupakan petugas satker wilayah Kabupaten Morowali yang mencairkan Dana Tugas Pembantuan (TP) melalui KPPN Poso. Keinginan satker tersebut, langsung ditindaklanjuti oleh Kepala KPPN Poso, dengan mengirimkan surat usulan pembentukan layanan filial KPPN Poso di Morowali kepada Kepala Kantor Wilayah Ditjen Perbendaharaan Provinsi Sulawesi Tengah, dengan tembusan kepada Bupati Morowali, dan Bupati Morowali Utara. Berbagai hal yang menjadi pertimbangan pembentukan layanan filial KPPN Poso di Morowali, diantaranya adalah letak geografis Kabupaten Morowali yang berjarak kurang lebih 250 km dari Kabupaten Poso, jumlah satker yang dilayani kurang lebih 30 satker, volume SPM kurang lebih mencapai 250 setiap bulannya, serta terdapatnya jaringan Visat yang mendukung operasional kantor. Pada tanggal 30 Juni 2016, akhirnya terbit Surat Keputusan Direktur Jenderal Perbendaharaan Nomor KEP- 
420/PB/2016 tanggal 30 Juni 2016 tentang Penetapan Kantor Pelayanan Perbendaharaan Negara Yang Menerapkan Layanan Filial Tahun 2016. Dalam surat keputusan tersebut, KPPN Poso diputuskan untuk membentuk layanan filial di Kabupaten Morowali.

\section{METODOLOGI PENELITIAN}

Pada bagian ini, penulis menguraikan metode/teknik yang digunakan untuk melakukan penelitian terhadap efektivitas layanan filial KPPN Poso di Morowali. Penelitian ini menggunakan studi deskriptif kuantitatif, dimana suatu permasalahan dicoba untuk dipecahkan melalui tahapan pengumpulan, dan penyusunan data-data, yang kemudian akan diolah, dianalisis, diinterpretasikan, dan disimpulkan agar pihak lain dapat memperoleh gambaran mengenai sifat dan karakteristik (Kuncoro, 2013).

\subsection{Objek Penelitian}

Objek penelitian ini adalah layanan filial KPPN Poso di Morowali, yang telah dibentuk bulan Oktober 2016 hingga kini. Untuk mengetahui pengaruh keberadaan layanan filial KPPN Poso di Morowali, dapat dilihat dengan membandingkan volume output layanan berupa Surat Perintah Pencairan Dana (SP2D), dan layanan konsultasi customer service officer yang dihasilkan KPPN Poso kepada satuan kerja wilayah Kabupaten Morowali dan Morowali Utara sebelum, dan sesudah layanan filial KPPN Poso di Morowali dibentuk.

\subsection{Jenis dan Sumber Data}

Jenis data yang digunakan dalam penelitian ini adalah data primer dan sekunder. Data primer merupakan data volume output layanan berupa SP2D, dan layanan konsultasi customer service officer dari Oktober 2015 sampai September 2016 berasal dari Kabupaten Morowali dan Kabupaten Morowali Utara sebelum adanya layanan filial KPPN Poso di Morowali, data volume output layanan berupa SP2D, dan layanan konsultasi customer service officer dari Oktober 2016 sampai September 2017 yang berasal dari Kabupaten Morowali dan Kabupaten Morowali Utara setelah adanya layanan filial KPPN Poso di Morowali. Datadata dimaksud diambil dari aplikasi Online Monitoring SPAN (OM SPAN) level KPPN Poso, dan laporan layanan filial KPPN Poso di Morowali yang telah disampaikan. Sedangkan, data sekunder merupakan data yang diperoleh langsung melalui wawancara dengan beberapa petugas satker Kabupaten Morowali serta Morowali Utara sebagai pengguna layanan filial KPPN Poso di Morowali.

\section{HASIL PENELITIAN}

\subsection{Kondisi Sebelum Adanya Layanan Filial KPPN Poso di Morowali}

Sebelum adanya layanan filial KPPN Poso di Morowali, satker wilayah Kabupaten Morowali dan Morowali Utara harus menempuh jarak kurang lebih $250 \mathrm{~km}$ untuk mendapatkan layanan KPPN Poso. Hal ini juga mempengaruhi jumlah tagihan yang diajukan satker Kabupaten Morowali dan Morowali Utara ke KPPN Poso. Berikut data jumlah tagihan yang diajukan oleh satuan kerja Kabupaten Morowali dan Morowali Utara periode Oktober 2015 sampai September 2016, atau sebelum dibentuknya Layanan Filial KPPN Poso di Morowali.

Tabel 1: Jumlah tagihan satuan kerja Kabupaten Morowali dan Morowali Utara sebelum adanya layanan filial KPPN Poso di Morowali periode Oktober 2015 sampai September 2016

\begin{tabular}{|c|c|c|}
\hline No. & Nama Satker & $\begin{array}{l}\text { Jumlah } \\
\text { SP2D }\end{array}$ \\
\hline 1. & $\begin{array}{lrr}\text { Badan } & \text { Narkotika } & \text { Nasional } \\
\text { Kabupuaten } & \text { Morowali } & \\
\end{array}$ & 100 \\
\hline 2. & Badan Pusat Statistik Kab. Morowali & 166 \\
\hline 3. & $\begin{array}{l}\text { Cabang Kejaksaan Negeri Morowali } \\
\text { Di Kolonodale }\end{array}$ & 87 \\
\hline 4. & $\begin{array}{lll}\text { Cabang Rumah } & \text { Tahanan } & \text { Negara } \\
\text { Kolonedale } & & \\
\end{array}$ & 177 \\
\hline 5. & $\begin{array}{lll}\text { Dinas Sosial, Tenaga Kerja } & \text { Dan } \\
\text { Transmigrasi Kab. Morowali } & \\
\end{array}$ & 308 \\
\hline 6. & $\begin{array}{lcr}\text { Kantor } & \text { Kementerian } & \text { Agama } \\
\text { Kabupaten } & \text { Morowali (635399) } \\
\end{array}$ & 167 \\
\hline 7. & $\begin{array}{lll}\text { Kantor } \quad \text { Kementerian } & \text { Agama } \\
\text { Kabupaten Morowali (635396) }\end{array}$ & 125 \\
\hline 8. & $\begin{array}{lll}\text { Kantor } & \text { Kementerian Agama } \\
\text { Kabupaten Morowali (635400) }\end{array}$ & 35 \\
\hline 9. & $\begin{array}{lll}\text { Kantor } & \text { Kementerian Agama } \\
\text { Kabupaten Morowali (635404) }\end{array}$ & 71 \\
\hline 10. & $\begin{array}{l}\text { Kantor Kementerian Agama } \\
\text { Kabupaten Morowali (635398) }\end{array}$ & 164 \\
\hline 11. & $\begin{array}{lll}\text { Kantor } \quad \text { Kementerian } & \text { Agama } \\
\text { Kabupaten Morowali (635397) }\end{array}$ & 174 \\
\hline 12. & $\begin{array}{l}\text { Kantor Pelayanan Penyuluhan Dan } \\
\text { Konsultasi Perpajakan Bungku }\end{array}$ & 76 \\
\hline 13. & $\begin{array}{lll}\begin{array}{l}\text { Kantor } \\
\text { Morowali }\end{array} & \text { Pertanahan } & \text { Kabupaten } \\
\end{array}$ & 193 \\
\hline 14. & Kejaksaan Negeri Morowali & 125 \\
\hline 15. & Kpu Kabupaten Morowali & 168 \\
\hline 16. & Kpu Kabupaten Morowali Utara & 183 \\
\hline 17. & $\begin{array}{l}\text { Madrasah Aliyah Negeri Bungku Kab. } \\
\text { Morowali }\end{array}$ & 156 \\
\hline 18. & $\begin{array}{lcc}\text { Madrasah } & \text { Tsanawiyah Negeri } \\
\text { Bungku Tengah Kab.Morowali } & \end{array}$ & 139 \\
\hline 19. & $\begin{array}{lll}\text { Madrasah } & \text { Tsanawiyah } & \text { Negeri } \\
\text { Bungku Utara Kab.Morowali } & \\
\end{array}$ & 167 \\
\hline 20. & $\begin{array}{l}\text { Madrasah Tsanawiyah Negeri Petasia } \\
\text { Kab. Morowali }\end{array}$ & 184 \\
\hline 21. & Pengadilan Agama Bungku & 104 \\
\hline 22. & Polres Morowali & 570 \\
\hline 23. & $\begin{array}{ll}\text { Unit Penyelenggara } & \text { Pelabuhan } \\
\text { Kolonedale } & \\
\end{array}$ & 257 \\
\hline \multicolumn{2}{|c|}{$\begin{array}{ll} & \text { Total } \\
\end{array}$} & 3.896 \\
\hline
\end{tabular}

Sumber: Aplikasi Online Monitoring SPAN level KPPN Poso Tahun 2015 dan 2016 (diolah) 
Sebanyak 23 satuan kerja di wilayah Kabupaten Morowali dan Morowali Utara, telah mengajukan total tagihan sebesar 3.896 ke KPPN Poso. Seluruh tagihan tersebut, diajukan sebelum adanya layanan filial KPPN Poso di Morowali. Melihat volume tagihan dan jumlah satker yang cukup banyak di wilayah Kabupaten Morowali dan Morowali Utara, maka KPPN Poso mengusulkan untuk dibentuk layanan filial di Morowali. Dengan keberadaan layanan filial KPPN Poso di Morowali, diharapkan memudahkan satuan kerja wilayah Kabupaten Morowali dan Morowali Utara untuk mendapatkan layanan dari KPPN Poso.

Untuk layanan konsultasi customer service officer pada KPPN Poso, terkait masalah perbendaharaan dilayani melalui tatap muka, dan tanpa tatap muka dengan petugas satuan kerja. Layanan konsultasi customer service officer secara tatap muka, dilakukan langsung di meja pelayanan. Sedangkan layanan konsultasi customer service officer tanpa tatap muka, dilakukan melalui telepon atau sarana komunikasi lainnya yang mendukung. Berikut data layanan konsultasi customer service officer yang langsung dilakukan di meja layanan kepada satuan kerja Kabupaten Morowali dan Morowali Utara periode Oktober 2015 sampai September 2016 atau sebelum dibentuknya Layanan Filial KPPN Poso di Morowali.

Tabel 2: Daftar jumlah layanan konsultasi pada meja layanan dari petugas satuan kerja Kabupaten Morowali dan Morowali Utara sebelum adanya layanan filial KPPN

Poso di Morowali periode Oktober 2015 sampai September 2016

\begin{tabular}{|l|c|l|c|}
\hline \multicolumn{1}{|c|}{ Bulan } & $\begin{array}{c}\text { Jumlah } \\
\text { Layanan } \\
\text { Konsultasi }\end{array}$ & Bulan & $\begin{array}{c}\text { Jumlah } \\
\text { Layanan } \\
\text { Konsultasi }\end{array}$ \\
\hline $\begin{array}{l}\text { Oktober } \\
2015\end{array}$ & 11 & $\begin{array}{l}\text { April } \\
2016\end{array}$ & 10 \\
\hline $\begin{array}{l}\text { November } \\
2015\end{array}$ & 11 & $\begin{array}{l}\text { Mei } \\
2016\end{array}$ & 13 \\
\hline $\begin{array}{l}\text { Desember } \\
2015\end{array}$ & 24 & $\begin{array}{l}\text { Juni } \\
2016\end{array}$ & 11 \\
\hline $\begin{array}{l}\text { Januari } \\
2016\end{array}$ & 12 & $\begin{array}{l}\text { Juli } \\
2016\end{array}$ & 10 \\
\hline $\begin{array}{l}\text { Februari } \\
2016\end{array}$ & 11 & $\begin{array}{l}\text { Agustus } \\
2016\end{array}$ & 5 \\
\hline $\begin{array}{l}\text { Maret } \\
2016\end{array}$ & 12 & $\begin{array}{l}\text { September } \\
2016\end{array}$ & 5 \\
\hline
\end{tabular}

Sumber: Laporan Rekapitulasi Penyuluh Perbendaharaan KPPN Poso Tahun 2015 dan 2016 (diolah)

Sesuai dengan PMK Nomor 190/PMK.05/2012 tentang Tata Cara Pembayaran Dalam Rangka Pelaksanaan APBN, disebutkan bahwa SPM Gaji Induk satker disampaikan ke KPPN paling lambat tanggal 15 sebelum bulan pembayaran. Jika satker terlambat menyampaikan SPM Gaji Induk, maka KPPN akan menerbitkan surat peringatan ke kepala satuan kerja atas keterlambatan penyampaian SPM Gaji Induk ke KPPN. Sebelum adanya layanan filial KPPN Poso di Morowali, beberapa satuan kerja wilayah Kabupaten Morowali dan Morowali Utara masih terlambat dalam menyampaikan gaji induk ke KPPN Poso. Bahkan, satker Polres Morowali mengalami keterlambatan pengajuan gaji induk ke KPPN Poso selama 5 kali, dalam periode sebelum adanya layanan filial KPPN Poso di Morowali. Berikut data satuan kerja yang terlambat mengajukan gaji induk ke KPPN Poso sebelum adanya layanan filial KPPN Poso di Morowali.

Tabel 3: Daftar satuan kerja Kabupaten Morowali dan Morowali Utara yang telat mengajukan gaji induk sebelum adanya layanan filial KPPN Poso di Morowali periode September 2015 sampai September 2016

\begin{tabular}{|c|c|c|c|}
\hline No. & $\begin{array}{c}\text { Satuan } \\
\text { Kerja }\end{array}$ & $\begin{array}{c}\text { Periode } \\
\text { Gaji }\end{array}$ & $\begin{array}{c}\text { Nomor dan Tanggal } \\
\text { Terbit Surat } \\
\text { Peringatan }\end{array}$ \\
\hline 1. & $\begin{array}{l}\text { Polres } \\
\text { Morowali }\end{array}$ & $\begin{array}{l}\text { Novemb } \\
\text { er } 2015\end{array}$ & $\begin{array}{ll}\text { S- } & \\
\text { 1023/WPB.26/KP.0 } \\
\text { 52/2015; } \quad 16 \\
\text { Oktober } 2015\end{array}$ \\
\hline 2. & $\begin{array}{c}\text { Kantor } \\
\text { Kementeria } \\
\text { n Agama } \\
\text { Kabupaten } \\
\text { Morowali } \\
(635396)\end{array}$ & $\begin{array}{c}\text { Desemb } \\
\text { er } \\
2015\end{array}$ & $\begin{array}{l}\text { S-1 } \\
\text { 364/WPB.26/KP.05 } \\
2 / 2015 ; 16 \\
\text { November } 2015\end{array}$ \\
\hline 3. & $\begin{array}{l}\text { Polres } \\
\text { Morowali }\end{array}$ & $\begin{array}{c}\text { Mei } \\
2016\end{array}$ & $\begin{array}{l}\text { S- } \\
\text { 562/WPB.26/KP.05 } \\
\text { 2/2016; } 19 \quad \text { April } \\
2016\end{array}$ \\
\hline 4. & $\begin{array}{l}\text { Polres } \\
\text { Morowali }\end{array}$ & $\begin{array}{l}\text { Juni } \\
2016\end{array}$ & $\begin{array}{l}\text { S- } \\
\text { 682/WPB.26/KP.05 } \\
\text { 2/2016; } 18 \text { Mei } 2016\end{array}$ \\
\hline 5. & $\begin{array}{l}\text { Polres } \\
\text { Morowali }\end{array}$ & Juli 2016 & $\begin{array}{l}\text { S- } \\
\text { 792/WPB.26/KP.05 } \\
2 / 2016 ; \quad 17 \quad \text { Juni } \\
2016\end{array}$ \\
\hline 6. & $\begin{array}{l}\text { Polres } \\
\text { Morowali }\end{array}$ & $\begin{array}{c}\text { Oktober } \\
2016\end{array}$ & $\begin{array}{l}\text { S- } \\
\text { 1170/WPB.26/KP.0 } \\
\text { 52/2016; } 19 \\
\text { September } 2016\end{array}$ \\
\hline 7. & $\begin{array}{l}\text { Kantor } \\
\text { Pelayanan } \\
\text { Penyuluhan } \\
\text { Dan } \\
\text { Konsultasi } \\
\text { Perpajakan } \\
\text { Bungku } \\
\end{array}$ & $\begin{array}{c}\text { Maret } \\
2016\end{array}$ & $\begin{array}{l}\text { S- } \\
\text { 319/WPB.26/KP.05 } \\
\text { 2/2016; 16 Februari } \\
2016\end{array}$ \\
\hline
\end{tabular}

Sumber: Daftar Monitoring Keterlambatan Gaji Induk Seksi Pencairan Dana KPPN Poso Tahun 2015 dan 2016 (diolah)

\subsection{Kondisi Setelah Adanya Layanan Filial KPPN Poso di Morowali}

Setelah adanya layanan filial KPPN Poso di Morowali, satker wilayah Kabupaten Morowali dan 
Morowali Utara dapat dengan mudah untuk mendapatkan layanan KPPN Poso. Hal ini juga mempengaruhi jumlah tagihan yang diajukan satuan kerja Kabupaten Morowali dan Morowali Utara ke KPPN Poso. Berikut data jumlah tagihan yang diajukan oleh satuan kerja Kabupaten Morowali dan Morowali Utara periode Oktober 2016 sampai September 2017, atau sesudah dibentuknya Layanan Filial KPPN Poso di Morowali.

Tabel 4: Jumlah tagihan satuan kerja Kabupaten Morowali dan Morowali Utara sesudah adanya layanan filial KPPN Poso di Morowali periode Oktober 2016 sampai September 2017

\begin{tabular}{|c|c|c|}
\hline No. & Nama Satker & $\begin{array}{l}\text { Jumlah } \\
\text { SP2D }\end{array}$ \\
\hline 1. & $\begin{array}{lrr}\text { Badan } & \text { Narkotika } & \text { Nasional } \\
\text { Kabupuaten } & \text { Morowali } & \\
\end{array}$ & 141 \\
\hline 2. & Badan Pusat Statistik Kab. Morowali & 231 \\
\hline 3. & $\begin{array}{l}\text { Cabang Kejaksaan Negeri Morowali } \\
\text { Di Kolonodale }\end{array}$ & 98 \\
\hline 4. & $\begin{array}{lll}\text { Cabang Rumah } & \text { Tahanan } & \text { Negara } \\
\text { Kolonedale } & & \\
\end{array}$ & 150 \\
\hline 5. & $\begin{array}{lll}\text { Dinas Sosial, Tenaga Kerja } & \text { Dan } \\
\text { Transmigrasi Kab. Morowali } & \\
\end{array}$ & 200 \\
\hline 6. & $\begin{array}{l}\text { Kantor } \quad \text { Kementerian Agama } \\
\text { Kabupaten Morowali (635399) }\end{array}$ & 168 \\
\hline 7. & $\begin{array}{lcc}\text { Kantor } & \text { Kementerian Agama } \\
\text { Kabupaten Morowali (635396) }\end{array}$ & 154 \\
\hline 8. & $\begin{array}{lll}\text { Kantor } & \text { Kementerian Agama } \\
\text { Kabupaten Morowali (635400) }\end{array}$ & 33 \\
\hline 9. & $\begin{array}{lcc}\text { Kantor } & \text { Kementerian } & \text { Agama } \\
\text { Kabupaten Morowali (635404) }\end{array}$ & 71 \\
\hline 10. & $\begin{array}{lcc}\text { Kantor } \quad \text { Kementerian } & \text { Agama } \\
\text { Kabupaten Morowali (635398) }\end{array}$ & 295 \\
\hline 11. & $\begin{array}{lcc}\text { Kantor } & \text { Kementerian Agama } \\
\text { Kabupaten Morowali (635397) }\end{array}$ & 161 \\
\hline 12. & $\begin{array}{l}\text { Kantor Pelayanan Penyuluhan Dan } \\
\text { Konsultasi Perpajakan Bungku }\end{array}$ & 94 \\
\hline 13. & $\begin{array}{lll}\text { Kantor } & \text { Pertanahan } & \text { Kabupaten } \\
\text { Morowali } & & \\
\end{array}$ & 242 \\
\hline 14. & Kejaksaan Negeri Morowali & 140 \\
\hline 15. & Kpu Kabupaten Morowali & 208 \\
\hline 16. & Kpu Kabupaten Morowali Utara & 182 \\
\hline 17. & $\begin{array}{l}\text { Madrasah Aliyah Negeri Bungku Kab. } \\
\text { Morowali }\end{array}$ & 199 \\
\hline 18. & $\begin{array}{lcc}\text { Madrasah } & \text { Tsanawiyah Negeri } \\
\text { Bungku Tengah Kab.Morowali } & \\
\end{array}$ & 144 \\
\hline 19. & $\begin{array}{lcc}\text { Madrasah } & \text { Tsanawiyah } & \text { Negeri } \\
\text { Bungku Utara Kab.Morowali } & \\
\end{array}$ & 135 \\
\hline 20. & $\begin{array}{l}\text { Madrasah Tsanawiyah Negeri Petasia } \\
\text { Kab. Morowali }\end{array}$ & 174 \\
\hline 21. & Pengadilan Agama Bungku & 115 \\
\hline 22. & Polres Morowali & 1.027 \\
\hline 23. & $\begin{array}{ll}\text { Unit Penyelenggara } & \text { Pelabuhan } \\
\text { Kolonedale } & \\
\end{array}$ & 228 \\
\hline 24. & $\begin{array}{lrr}\text { Kantor } & \text { Kementerian } & \text { Agama } \\
\text { Kabupaten } & \text { Morowali Utara } & (418432) \\
\end{array}$ & 19 \\
\hline 25. & $\begin{array}{lrr}\text { Kantor } & \text { Kementerian } & \text { Agama } \\
\text { Kabupaten } & \text { Morowali Utara (418483) }\end{array}$ & 33 \\
\hline 26. & $\begin{array}{lrr}\text { Kantor } & \text { Kementerian } & \text { Agama } \\
\text { Kabupaten } & \text { Morowali Utara (418910) } \\
\end{array}$ & 106 \\
\hline
\end{tabular}

\begin{tabular}{|c|c|c|}
\hline 27. & 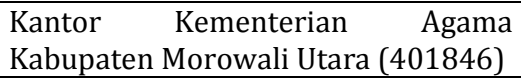 & 73 \\
\hline 28. & $\begin{array}{lrr}\text { Kantor } \quad \text { Kementerian } & \text { Agama } \\
\text { Kabupaten } & \text { Morowali Utara } & (418012) \\
\end{array}$ & 39 \\
\hline & Total & 4.863 \\
\hline
\end{tabular}

Sumber: Aplikasi Online Monitoring SPAN level KPPN Poso Tahun 2016 dan 2017 (diolah)

Sebanyak 28 satuan kerja di wilayah Kabupaten Morowali dan Morowali Utara telah mengajukan total tagihan sebesar 4.863 ke KPPN Poso. Seluruh tagihan tersebut diajukan setelah adanya layanan filial KPPN Poso di Morowali.

Layanan filial KPPN Poso di Morowali mencakup pula konsultasi customer service officer. Layanan konsultasi customer service officer dilakukan sama seperti yang ada di KPPN Poso, yaitu melalui tatap muka, dan tanpa tatap muka dengan petugas satker. Layanan konsultasi customer service officer secara tatap muka dilakukan langsung di meja pelayanan filial KPPN Poso di Morowali. Sedangkan layanan konsultasi customer service officer tanpa tatap muka, dilakukan melalui telepon atau sarana komunikasi lainnya yang mendukung. Berikut data layanan konsultasi customer service officer yang langsung dilakukan di meja layanan filial KPPN Poso di Morowali, periode Oktober 2016 sampai September 2017, atau sesudah dibentuknya Layanan Filial KPPN Poso di Morowali.

Tabel 5: Daftar jumlah layanan konsultasi pada meja layanan dari petugas satuan kerja Kabupaten Morowali dan Morowali Utara setelah adanya layanan filial KPPN

Poso di Morowali periode Oktober 2016 sampai September 2017

\begin{tabular}{|l|c|l|c|}
\hline \multicolumn{1}{|c|}{ Bulan } & $\begin{array}{c}\text { Jumlah } \\
\text { Layanan } \\
\text { Konsultasi }\end{array}$ & Bulan & $\begin{array}{c}\text { Jumlah } \\
\text { Layanan } \\
\text { Konsultasi }\end{array}$ \\
\hline $\begin{array}{l}\text { Oktober } \\
2016\end{array}$ & 18 & $\begin{array}{l}\text { April } \\
2017\end{array}$ & 12 \\
\hline $\begin{array}{l}\text { November } \\
2016\end{array}$ & 13 & $\begin{array}{l}\text { Mei } \\
2017\end{array}$ & 14 \\
\hline $\begin{array}{l}\text { Desember } \\
2016\end{array}$ & 14 & $\begin{array}{l}\text { Juni } \\
2017\end{array}$ & 12 \\
\hline $\begin{array}{l}\text { Januari } \\
2017\end{array}$ & 13 & $\begin{array}{l}\text { Juli } \\
2017\end{array}$ & 15 \\
\hline $\begin{array}{l}\text { Februari } \\
2017\end{array}$ & 10 & $\begin{array}{l}\text { Agustus } \\
2017\end{array}$ & 13 \\
\hline $\begin{array}{l}\text { Maret } \\
2017\end{array}$ & 18 & $\begin{array}{l}\text { September } \\
2017\end{array}$ & 16 \\
\hline
\end{tabular}

Sumber: Laporan Rekapitulasi Penyuluh Perbendaharaan KPPN Poso Tahun 2016 dan 2017 (diolah)

Setelah adanya layanan filial KPPN Poso di Morowali, masih terdapat beberapa satker wilayah Kabupaten Morowali dan Morowali Utara yang mengalami keterlambatan dalam mengajukan gaji induk ke KPPN Poso. Namun, keterlambatan tersebut tidak disebabkan oleh kendala jarak yang 
ditempuh untuk mengajukan SPM Gaji Induk ke KPPN Poso. Hal tersebut disampaikan oleh petugas satker yang terlambat dalam mengajukan SPM Gaji Induk ke KPPN Poso. Alasan para petugas satker pun beragam, diantaranya adalah operator gaji yang sedang melaksanakan cuti atau dinas luar, hingga menunggu Surat Keterangan Penghentian Pembayaran (SKPP) gaji pegawai baru masuk ke satker untuk diajukan gaji induknya ke KPPN. Berikut data satuan kerja yang terlambat mengajukan gaji induk ke KPPN Poso, setelah adanya layanan filial KPPN Poso di Morowali.

Tabel 6: Daftar satuan kerja Kabupaten Morowali dan Morowali Utara yang telat mengajukan gaji induk sesudah adanya layanan filial KPPN Poso di Morowali periode Oktober 2016 sampai September 2017

\begin{tabular}{|c|c|c|c|}
\hline No. & Satuan Kerja & $\begin{array}{l}\text { Periode } \\
\text { Gaji }\end{array}$ & $\begin{array}{c}\text { Nomor dan } \\
\text { Tanggal Terbit } \\
\text { Surat } \\
\text { Peringatan }\end{array}$ \\
\hline 1. & $\begin{array}{l}\text { Kementerian } \\
\text { Agama } \\
\text { Kabupaten } \\
\text { Morowali Utara }\end{array}$ & $\begin{array}{l}\text { April } \\
2017\end{array}$ & $\begin{array}{l}\text { S- } \\
\text { 590/WPB.26/KP } \\
.052 / 2017 ; \\
\text { Maret } 2017\end{array}$ \\
\hline 2. & $\begin{array}{l}\text { Kejaksaan } \\
\text { Negeri } \\
\text { Morowali }\end{array}$ & Mei 2017 & $\begin{array}{l}\text { S- } \\
\text { 344/WPB.26/KP } \\
.052 / 2017 ; \\
\text { April 2017 }\end{array}$ \\
\hline 3. & $\begin{array}{l}\text { Polres } \\
\text { Morowali }\end{array}$ & $\begin{array}{l}\text { April } \\
2017\end{array}$ & $\begin{array}{l}\text { S- } \\
\text { 247/WPB.26/KP } \\
.052 / 2017 ; \\
\text { Maret 2017 }\end{array}$ \\
\hline 4. & $\begin{array}{l}\text { MTS N Bungku } \\
\text { Utara }\end{array}$ & $\begin{array}{l}\text { April } \\
2017\end{array}$ & $\begin{array}{l}\text { S- } \\
\text { 249/WPB.26/KP } \\
.052 / 2017 ; 16 \\
\text { Maret } 2017\end{array}$ \\
\hline
\end{tabular}

Sumber: Daftar Monitoring Keterlambatan Gaji Induk Seksi Pencairan Dana KPPN Poso Tahun 2016 dan 2017

\subsection{Pengaruh Keberadaan Adanya Layanan Filial KPPN Poso di Morowali}

Secara langsung maupun tidak langsung, adanya layanan filial KPPN Poso di Morowali memiliki dampak kepada satker wilayah Kabupaten Morowali dan Morowali Utara. Salah satu dampaknya adalah bertambahnya jumlah tagihan yang masuk ke KPPN Poso, yang berasal dari sejumlah satuan kerja Kabupaten Morowali dan Morowali Utara. Berikut ini ditampilkan perubahan jumlah tagihan yang masuk ke KPPN Poso, sebelum dan sesudah adanya layanan filial KPPN Poso di Morowali.
Tabel 7: Jumlah tagihan satuan kerja Kabupaten Morowali dan Morowali Utara sebelum dan sesudah adanya layanan filial KPPN Poso di Morowali

\begin{tabular}{|c|c|c|c|c|}
\hline No. & Nama Satker & $\begin{array}{l}\text { Jumlah } \\
\text { SP2D } \\
\text { (Sebelum } \\
\text { Adanya } \\
\text { Layanan } \\
\text { Filial) }\end{array}$ & $\begin{array}{c}\text { Jumlah } \\
\text { SP2D } \\
\text { (Setelah } \\
\text { Adanya } \\
\text { Layanan } \\
\text { Filial) }\end{array}$ & Selisih \\
\hline 1. & $\begin{array}{l}\text { Badan } \\
\text { Narkotika } \\
\text { Nasional } \\
\text { Kabupuaten } \\
\text { Morowali }\end{array}$ & 100 & 141 & +41 \\
\hline 2. & $\begin{array}{l}\text { Badan Pusat } \\
\text { Statistik Kab. } \\
\text { Morowali }\end{array}$ & 166 & 234 & +68 \\
\hline 3. & $\begin{array}{l}\text { Cabang } \\
\text { Kejaksaan } \\
\text { Negeri } \\
\text { Morowali Di } \\
\text { Kolonodale } \\
\end{array}$ & 87 & 98 & +11 \\
\hline 4. & $\begin{array}{l}\text { Cabang } \\
\text { Rumah } \\
\text { Tahanan } \\
\text { Negara } \\
\text { Kolonedale }\end{array}$ & 177 & 150 & -22 \\
\hline 5. & $\begin{array}{l}\text { Dinas Sosial, } \\
\text { Tenaga Kerja } \\
\text { Dan } \\
\text { Transmigrasi } \\
\text { Kab. } \\
\text { Morowali }\end{array}$ & 308 & 200 & -108 \\
\hline 6. & $\begin{array}{l}\text { Kantor } \\
\text { Kementerian } \\
\text { Agama } \\
\text { Kabupaten } \\
\text { Morowali } \\
(635399)\end{array}$ & 167 & 168 & +1 \\
\hline 7. & $\begin{array}{l}\text { Kantor } \\
\text { Kementerian } \\
\text { Agama } \\
\text { Kabupaten } \\
\text { Morowali } \\
(635396)\end{array}$ & 125 & 154 & +29 \\
\hline 8. & $\begin{array}{l}\text { Kantor } \\
\text { Kementerian } \\
\text { Agama } \\
\text { Kabupaten } \\
\text { Morowali } \\
(635400)\end{array}$ & 35 & 33 & -2 \\
\hline 9. & $\begin{array}{l}\text { Kantor } \\
\text { Kementerian } \\
\text { Agama } \\
\text { Kabupaten } \\
\text { Morowali } \\
(635404)\end{array}$ & 71 & 71 & 0 \\
\hline 10. & $\begin{array}{l}\text { Kantor } \\
\text { Kementerian } \\
\text { Agama } \\
\text { Kabupaten } \\
\text { Morowali } \\
\text { (635398) }\end{array}$ & 164 & 295 & +131 \\
\hline 11. & Kantor & 174 & 161 & -13 \\
\hline
\end{tabular}




\begin{tabular}{|c|c|c|c|c|}
\hline & $\begin{array}{l}\text { Kementerian } \\
\text { Agama } \\
\text { Kabupaten } \\
\text { Morowali } \\
(635397)\end{array}$ & & & \\
\hline 12. & $\begin{array}{l}\text { Kantor } \\
\text { Pelayanan } \\
\text { Penyuluhan } \\
\text { Dan } \\
\text { Konsultasi } \\
\text { Perpajakan } \\
\text { Bungku }\end{array}$ & 76 & 94 & +18 \\
\hline 13. & $\begin{array}{l}\text { Kantor } \\
\text { Pertanahan } \\
\text { Kabupaten } \\
\text { Morowali }\end{array}$ & 193 & 242 & +49 \\
\hline 14. & $\begin{array}{l}\text { Kejaksaan } \\
\text { Negeri } \\
\text { Morowali }\end{array}$ & 125 & 140 & +15 \\
\hline 15. & $\begin{array}{l}\text { Kpu } \\
\text { Kabupaten } \\
\text { Morowali }\end{array}$ & 168 & 208 & +40 \\
\hline 16. & $\begin{array}{l}\text { Kpu } \\
\text { Kabupaten } \\
\text { Morowali } \\
\text { Utara }\end{array}$ & 183 & 182 & -1 \\
\hline 17. & $\begin{array}{l}\text { Madrasah } \\
\text { Aliyah Negeri } \\
\text { Bungku Kab. } \\
\text { Morowali }\end{array}$ & 156 & 199 & +43 \\
\hline 18. & $\begin{array}{l}\text { Madrasah } \\
\text { Tsanawiyah } \\
\text { Negeri } \\
\text { Bungku } \\
\text { Tengah } \\
\text { Kab.Morowali }\end{array}$ & 139 & 144 & +5 \\
\hline 19. & $\begin{array}{l}\text { Madrasah } \\
\text { Tsanawiyah } \\
\text { Negeri } \\
\text { Bungku Utara } \\
\text { Kab.Morowali }\end{array}$ & 167 & 135 & -32 \\
\hline 20. & $\begin{array}{l}\text { Madrasah } \\
\text { Tsanawiyah } \\
\text { Negeri } \\
\text { Petasia Kab. } \\
\text { Morowali }\end{array}$ & 184 & 174 & -10 \\
\hline 21. & $\begin{array}{l}\text { Pengadilan } \\
\text { Agama } \\
\text { Bungku }\end{array}$ & 104 & 115 & +11 \\
\hline 22. & $\begin{array}{l}\text { Polres } \\
\text { Morowali }\end{array}$ & 570 & 1.027 & +457 \\
\hline 23. & $\begin{array}{l}\text { Unit } \\
\text { Penyelenggar } \\
\text { a Pelabuhan } \\
\text { Kolonedale }\end{array}$ & 257 & 228 & -29 \\
\hline 24. & $\begin{array}{l}\text { Kantor } \\
\text { Kementerian } \\
\text { Agama } \\
\text { Kabupaten } \\
\text { Morowali } \\
\text { Utara } \\
(418432)\end{array}$ & 0 & 19 & +19 \\
\hline 25. & $\begin{array}{l}\text { Kantor } \\
\text { Kementerian } \\
\text { Agama }\end{array}$ & 0 & 33 & +33 \\
\hline
\end{tabular}

\begin{tabular}{|c|l|c|c|c|}
\hline & $\begin{array}{l}\text { Kabupaten } \\
\text { Morowali } \\
\text { Utara } \\
(418483)\end{array}$ & & & \\
\hline 26. & $\begin{array}{l}\text { Kantor } \\
\text { Kementerian } \\
\text { Agama } \\
\text { Kabupaten } \\
\text { Morowali } \\
\text { Utara } \\
(418910)\end{array}$ & 0 & 106 & +106 \\
\hline 27. & $\begin{array}{l}\text { Kantor } \\
\text { Kementerian } \\
\text { Agama } \\
\text { Kabupaten } \\
\text { Morowali } \\
\text { Utara } \\
\text { (401846) }\end{array}$ & 0 & 73 & +73 \\
\hline 28. & $\begin{array}{l}\text { Kantor } \\
\text { Kementerian } \\
\text { Agama } \\
\text { Kabupaten } \\
\text { Morowali } \\
\text { Utara } \\
\text { (418012) }\end{array}$ & & & \\
\hline \multicolumn{1}{|c|}{ Total } & 3.896 & 4.863 & +967 \\
\hline
\end{tabular}

Sumber: Aplikasi Online Monitoring SPAN level KPPN Poso Tahun 2015, 2016 dan 2017 (diolah)

Pada tabel diatas terdapat 19 satuan kerja Kabupaten Morowali dan Morowali Utara yang mengalami kenaikan jumlah tagihan yang disampaikan ke KPPN Poso sejak layanan filial KPPN Poso di Morowali dibuka. Terdapat 8 satuan kerja Kabupaten Morowali dan Morowali Utara yang mengalami penurunan jumlah tagihan yang disampaikan ke layanan filial KPPN Poso di Morowali. Terdapat 6 satker baru di Kabupaten Morowali Utara, yaitu Kementerian Agama Kabupaten Morowali Utara yang memanfaatkan layanan filial KPPN Poso di Morowali, hal tersebut juga berpengaruh terhadap kenaikan jumlah tagihan yang disampaikan ke KPPN Poso sejak layanan filial KPPN Poso di Morowali dibuka. Kenaikan jumlah tagihan sebesar 967 selama layanan filial KPPN Poso di Morowali, mengindikasikan bahwa keberadaan layanan filial KPPN Poso di Morowali sangat dimanfaatkan oleh seluruh satker wilayah Kabupaten Morowali dan Kabupaten Morowali Utara. Dengan hadirnya layanan filial KPPN Poso di Morowali, satker wilayah Kabupaten Morowali dan Kabupaten Morowali Utara dapat dengan mudah mendapatkan layanan dari KPPN Poso.

Untuk layanan konsultasi customer service officer secara tatap muka, tetap dapat dilakukan langsung di meja pelayanan filial KPPN Poso di Morowali. Berikut ini ditampilkan perubahan jumlah layanan konsultasi customer service officer yang diterima petugas satuan kerja Kabupaten 
Morowali dan Morowali Utara secara tatap muka, sebelum dan sesudah adanya layanan filial KPPN Poso di Morowali.

Tabel 8: Jumlah layanan konsultasi customer service officer Kabupaten Morowali dan Morowali Utara sebelum dan sesudah adanya layanan filial KPPN Poso di Morowali

\begin{tabular}{|c|c|c|c|c|}
\hline Bulan & $\begin{array}{c}\text { Jumlah } \\
\text { Layanan } \\
\text { Konsultasi }\end{array}$ & Bulan & $\begin{array}{c}\text { Jumlah } \\
\text { Layanan } \\
\text { Konsultasi }\end{array}$ & Selisih \\
\hline $\begin{array}{l}\text { Okt } \\
2015\end{array}$ & 11 & $\begin{array}{l}\text { Okt } \\
2016\end{array}$ & 18 & +7 \\
\hline $\begin{array}{l}\text { Nov } \\
2015\end{array}$ & 11 & $\begin{array}{l}\text { Nov } \\
2016\end{array}$ & 13 & +2 \\
\hline $\begin{array}{l}\text { Des } \\
2015\end{array}$ & 24 & $\begin{array}{l}\text { Des } \\
2016\end{array}$ & 14 & -10 \\
\hline $\begin{array}{l}\text { Jan } \\
2016\end{array}$ & 12 & $\begin{array}{l}\text { Jan } \\
2017\end{array}$ & 13 & +1 \\
\hline $\begin{array}{l}\text { Feb } \\
2016\end{array}$ & 11 & $\begin{array}{l}\text { Feb } \\
2017\end{array}$ & 10 & -1 \\
\hline $\begin{array}{l}\text { Mar } \\
2016\end{array}$ & 12 & $\begin{array}{l}\text { Mar } \\
2017\end{array}$ & 18 & +6 \\
\hline $\begin{array}{l}\text { Apr } \\
2016\end{array}$ & 10 & $\begin{array}{l}\text { Apr } \\
2017\end{array}$ & 12 & +2 \\
\hline $\begin{array}{l}\text { Mei } \\
2016\end{array}$ & 13 & $\begin{array}{l}\text { Mei } \\
2017\end{array}$ & 14 & +1 \\
\hline $\begin{array}{l}\text { Juni } \\
2016\end{array}$ & 11 & $\begin{array}{l}\text { Juni } \\
2017\end{array}$ & 12 & +1 \\
\hline $\begin{array}{l}\text { Juli } \\
2016\end{array}$ & 10 & $\begin{array}{l}\text { Juli } \\
2017\end{array}$ & 15 & +5 \\
\hline $\begin{array}{l}\text { Agst } \\
2016\end{array}$ & 5 & $\begin{array}{l}\text { Agst } \\
2017\end{array}$ & 13 & +8 \\
\hline $\begin{array}{l}\text { Sept } \\
2016\end{array}$ & 5 & $\begin{array}{l}\text { Sept } \\
2017\end{array}$ & 16 & +11 \\
\hline Total & 135 & Total & 168 & +33 \\
\hline
\end{tabular}

Sumber: Laporan Rekapitulasi Penyuluh Perbendaharaan KPPN Poso Tahun 2015, 2016, dan 2017 (diolah)

Pada tabel diatas terdapat kenaikan jumlah layanan konsultasi customer service officer secara tatap muka sekitar 19\%, setelah adanya layanan filial KPPN Poso di Morowali. Secara jumlah, kenaikan layanan konsultasi customer service officer secara tatap muka tidak begitu signifikan, rata-rata pada setiap bulannya hanya pada bulanbulan tertentu terjadi kenaikan yang tinggi. Hal ini disebabkan oleh petugas satker Kabupaten Morowali dan Morowali Utara lebih memilih layanan konsultasi customer service officer tanpa tatap muka yang dilakukan melalui telepon, atau lainnya, daripada harus melalui meja layanan konsultasi yang ada di layanan filial KPPN Poso di Morowali.

Keberadaan layanan filial KPPN Poso di Morowali juga berdampak pada ketepatan waktu penyampaian SPM gaji induk ke KPPN Poso.
Terdapat penurunan keterlambatan satker dalam menyampaikan SPM gaji induk ke KPPN Poso, meskipun penurunan tersebut tidak signifikan. Untuk satuan kerja Polres Morowali, terdapat peningkatan ketepatan waktu dalam menyampaikan SPM gaji induk yang sebelum adanya layanan filial KPPN Poso di Morowali mengalami keterlambatan sebanyak 4 kali, namun sesudah adanya layanan filial KPPN Poso di Morowali keterlambatan itu menjadi hanya 1 kali.

Tabel 9: Daftar satuan kerja Kabupaten Morowali dan Morowali Utara yang terlambat menyampaikan SPM Gaji Induk sebelum dan sesudah adanya layanan filial KPPN Poso di Morowali

\begin{tabular}{|c|c|c|c|}
\hline \multicolumn{2}{|c|}{$\begin{array}{l}\text { Sebelum Adanya Filial } \\
\text { KPPN Poso di Morowali }\end{array}$} & \multicolumn{2}{|c|}{$\begin{array}{l}\text { Sesudah Adanya Filial } \\
\text { KPPN Poso di Morowali }\end{array}$} \\
\hline Satuan Kerja & $\begin{array}{c}\text { Periode } \\
\text { Gaji }\end{array}$ & $\begin{array}{c}\text { Satuan } \\
\text { Kerja }\end{array}$ & $\begin{array}{l}\text { Periode } \\
\text { Gaji }\end{array}$ \\
\hline $\begin{array}{l}\text { Polres } \\
\text { Morowali }\end{array}$ & $\begin{array}{c}\text { November } \\
2015\end{array}$ & $\begin{array}{l}\text { Kementeria } \\
\text { n Agama } \\
\text { Kabupaten } \\
\text { Morowali } \\
\text { Utara }\end{array}$ & April 2017 \\
\hline $\begin{array}{l}\text { Kantor } \\
\text { Kementerian } \\
\text { Agama } \\
\text { Kabupaten } \\
\text { Morowali } \\
(635396)\end{array}$ & $\begin{array}{l}\text { Desember } \\
2015\end{array}$ & $\begin{array}{l}\text { Kejaksaan } \\
\text { Negeri } \\
\text { Morowali }\end{array}$ & Mei 2017 \\
\hline $\begin{array}{l}\text { Polres } \\
\text { Morowali }\end{array}$ & Mei 2016 & $\begin{array}{l}\text { Polres } \\
\text { Morowali }\end{array}$ & April 2017 \\
\hline $\begin{array}{l}\text { Polres } \\
\text { Morowali }\end{array}$ & Juni 2016 & $\begin{array}{l}\text { MTSN } \\
\text { Bungku } \\
\text { Utara }\end{array}$ & April 2017 \\
\hline $\begin{array}{l}\text { Polres } \\
\text { Morowali }\end{array}$ & Juli 2016 & - & - \\
\hline $\begin{array}{l}\text { Polres } \\
\text { Morowali }\end{array}$ & $\begin{array}{l}\text { Oktober } \\
2016\end{array}$ & - & - \\
\hline $\begin{array}{l}\text { Kantor } \\
\text { Pelayanan } \\
\text { Penyuluhan } \\
\text { Dan } \\
\text { Konsultasi } \\
\text { Perpajakan } \\
\text { Bungku }\end{array}$ & Maret 2016 & - & - \\
\hline
\end{tabular}

Sumber: Daftar Monitoring Keterlambatan Gaji Induk Seksi Pencairan Dana KPPN Poso Tahun 2015, 2016, dan 2017 (diolah)

Adanya layanan filial KPPN Poso di Morowali juga mempengaruhi penerimaan SPM front office di KPPN Poso. Volume penerimaan SPM di front office KPPN Poso menjadi berkurang, karena seluruh satker Kabupaten Morowali dan Morowali Utara menyampaikan SPM di layanan filial. Berikut daftar jumlah SPM yang diterima di KPPN Poso dengan layanan filial KPPN Poso di Morowali. 
Tabel 10:Daftar jumlah penerbitan SP2D sesudah adanya layanan filial KPPN Poso di Morowali

\begin{tabular}{|c|c|c|c|c|}
\hline \multirow[b]{2}{*}{ No. } & \multirow[b]{2}{*}{ Bulan } & \multicolumn{2}{|c|}{$\begin{array}{c}\text { Jumlah SP2D yang } \\
\text { diterbitkan }\end{array}$} & \multirow{2}{*}{$\begin{array}{c}\text { Persentase } \\
\text { SP2D } \\
\text { diterima di } \\
\text { Filial }\end{array}$} \\
\hline & & Filial & $\begin{array}{c}\text { Filial + } \\
\text { Induk }\end{array}$ & \\
\hline 1 & $\begin{array}{l}\text { Oktober } \\
2016\end{array}$ & 281 & 1.101 & $19.5 \%$ \\
\hline 2 & $\begin{array}{l}\text { November } \\
2016\end{array}$ & 544 & 1.436 & $26.3 \%$ \\
\hline 3 & $\begin{array}{l}\text { Desember } \\
2016\end{array}$ & 673 & 2.179 & $30.8 \%$ \\
\hline 4 & $\begin{array}{l}\text { Januari } \\
2017\end{array}$ & 64 & 342 & $18.7 \%$ \\
\hline 5 & $\begin{array}{l}\text { Februari } \\
2017 \\
\end{array}$ & 153 & 872 & $17.5 \%$ \\
\hline 6 & Maret 2017 & 182 & 1.177 & $15.5 \%$ \\
\hline 7 & April 2017 & 285 & 1.143 & $24.9 \%$ \\
\hline 8 & Mei 2017 & 160 & 1.209 & $13.2 \%$ \\
\hline 9 & Juni 2017 & 422 & 1.251 & $33,7 \%$ \\
\hline 10 & Juli 2017 & 250 & 1.115 & $22.4 \%$ \\
\hline 11 & $\begin{array}{l}\text { Agustus } \\
2017 \\
\end{array}$ & 265 & 1.130 & $23,4 \%$ \\
\hline 12 & $\begin{array}{l}\text { September } \\
2017\end{array}$ & 322 & 1.199 & $26,8 \%$ \\
\hline
\end{tabular}

Sumber: Laporan Evaluasi Pelaksanaan Layanan Filial KPPN Poso di Morowali (diolah)

Dari tabel diatas, dapat dilihat bahwa setiap bulannya SPM yang diterima pada layanan filial KPPN Poso di Morowali rata-rata sekitar 22\%, dari total SPM yang diproses menjadi SP2D oleh KPPN Poso. Dengan persentase tersebut, menunjukkan bahwa keberadaan layanan filial KPPN Poso di Morowali memudahkan satuan kerja wilayah Kabupaten Morowali dan Morowali Utara untuk mencairkan tagihannya ke KPPN Poso.

\section{KESIMPULAN DAN SARAN}

Hasil penelitian pada bab sebelumnya, menunjukkan bahwa terjadi peningkatan tagihan yang diajukan oleh satuan kerja wilayah Kabupaten Morowali dan Morowali Utara setelah adanya layanan filial KPPN Poso di Morowali. Keberadaan layanan filial KPPN Poso di Morowali, juga berdampak pada ketepatan satuan kerja dalam mengajukan SPM gaji induk, karena sejak adanya layanan filial berjalan satker yang terlambat dalam mengajukan SPM gaji induk cenderung menurun. Layanan filial KPPN Poso di Morowali juga mempengaruhi penerimaan SPM di front office KPPN Poso, karena sekitar 22\% SP2D yang diterbitkan oleh KPPN Poso pada tiap bulannya berasal dari penerimaan SPM di layanan filial KPPN Poso di Morowali. Untuk layanan konsultasi customer service officer secara tatap muka terjadi kenaikan sekitar 19\% setelah adanya layanan filial KPPN Poso di Morowali.
Berdasarkan hasil tersebut, dapat disimpulkan bahwa keberadaan layanan filial KPPN Poso di Morowali sangat bermanfaat bagi satuan kerja wilayah Kabupaten Morowali dan Morowali Utara. Selain itu, keberadaan layanan filial KPPN Poso di Morowali terbukti memudahkan satuan kerja wilayah Kabupaten Morowali dan Morowali Utara untuk mendapatkan layanan dari KPPN Poso.

Berdasarkan kesimpulan diatas, maka saran yang dapat diberikan adalah melihat Kabupaten Morowali adalah kabupaten yang baru berdiri, dan Kabupaten Morowali Utara merupakan daerah pemekaran dari Kabupaten Morowali, maka dibutuhkan dana cukup besar yang bersumber dari APBN untuk mengembangkan wilayah tersebut, sehingga perlu didirikan KPPN di daerah tersebut. Belum lagi adanya wacana ke depan, bahwa akan adanya pembentukan Provinsi Sulawesi Timur dengan Kabupaten Morowali dan Kabupaten Morowali Utara terdapat di dalamnya.

\section{IMPLIKASI DAN KETERBATASAN}

Penulis menyadari dalam penulisan ini masih terdapat kekurangan dalam menjelaskan masalah yang diangkat dalam penelitian ini. Keterbatasan penelitian ini antara lain:

1. Penelitian ini belum menyertakan layanan lainnya yang diberikan oleh KPPN seperti konfirmasi penerimaan dan rekonsiliasi laporan keuangan.

2. Objek penelitian yang digunakan hanya mencakup layanan filial di Kabupaten Morowali. Penelitian selanjutnya sebaiknya menambah objek penelitian wilayah-wilayah lain di Indonesia yang terdapat layanan filial KPPN.

\section{PENGHARGAAN}

Penulis menyadari bahwa dalam proses penyusunan penelitian ini tidak lepas dari bantuan, dukungan, dan arahan dari berbagai pihak. Oleh karena itu, pada kesempatan ini penulis ingin mengucapkan terima kasih sebesar-besarnya.

\section{DAFTAR PUSTAKA}

Kuncoro,Mudrajad (2013). Metode Riset untuk Bisnis \& Ekonomi, Edisi Keempat. Jakarta: Erlangga.

Tim Penyusun (2016). Profil Kantor Pelayanan Perbendaharaan Negara. Poso.

Direktorat Jenderal Perbendaharaan (2015). Online Monitoring SPAN. Retrieved from Online Monitoring SPAN website: http://www.spanint.kemenkeu.go.id 
Direktorat Jenderal Perbendaharaan (2016). Online Monitoring SPAN. Retrieved from Online Monitoring SPAN website: http://www.spanint.kemenkeu.go.id

Direktorat Jenderal Perbendaharaan (2017). Online Monitoring SPAN. Retrieved from Online Monitoring SPAN website: http://www.spanint.kemenkeu.go.id

KPPN Poso. (2016). Laporan Evaluasi Layanan Filial KPPN Poso di Morowali . Laporan, Tidak Dipublikasikan.

KPPN Poso. (2017). Laporan Evaluasi Layanan Filial KPPN Poso di Morowali . Laporan, Tidak Dipublikasikan. 